1987

\title{
Major League Baseball's Monopoly Power and the Negro Leagues
}

\author{
Alfred Dennis Mathewson \\ University of New Mexico - School of Law
}

Follow this and additional works at: https://digitalrepository.unm.edu/law_facultyscholarship

Part of the Law Commons

\section{Recommended Citation}

Alfred D. Mathewson, Major League Baseball's Monopoly Power and the Negro Leagues, American Business Law Journal 291 (1987).

Available at: https://digitalrepository.unm.edu/law_facultyscholarship/395

This Article is brought to you for free and open access by the UNM School of Law at UNM Digital Repository. It has been accepted for inclusion in Faculty Scholarship by an authorized administrator of UNM Digital Repository. For more information, please contact amywinter@unm.edu, Isloane@salud.unm.edu,sarahrk@unm.edu.

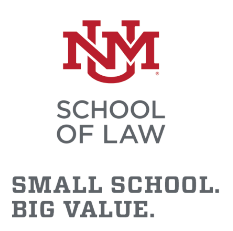

BIG VALUE. 


\section{MAJOR LEAGUE BASEBALL'S MONOPOLY POWER AND THE NEGRO LEAGUES}

*ALFRED DENNIS MATHEWSON

Fifty years have passed since Branch Rickey lured Jackie Robinson from the Kansas City Monarchs to play for the Brooklyn Dodgers. Nearly thirty years have passed since the Indianapolis Clowns, the last surviving Negro League team, closed its doors and ceased to play ball. Historians attribute this failure to integration. This article challenges that view. It is true that the very existence of teams of Black players (usually with Black owners) was due to the exclusion of Black players from "Organized Baseball." The formation of the Negro Leagues also resulted from, but did not necessarily occur because of, the purposeful segregation of the Major Leagues. Their establishment was driven by economics; team owners were trying to improve the quality of their product and profitability. Whatever the cause for their existence, the survival of organizations like the American Tennis Association (ATA), the Harlem Globetrotters and Black college sports in general demonstrates that the demise of the Negro Leagues was not an inevitable consequence of the Major Leagues' inclusion of Black players.

* Associate Dean and Professor of Law, University of New Mexico. An earlier version of this article was presented at the 1996 Annual Meeting of the Association for the Study of Afro-American Life and History. I wish to express my appreciation to my research assistant, Keith Borden, a proud Morehouse alumnus, without whom the completion of this article would not have been possible.

${ }^{1}$ See infra note 82 and accompanying text (discussing Major League Baseball's failure to accept negro players). 
This article argues that the demise of the Negro Leagues was caused by the confluence of several factors. First, the Negro Leagues operated with weak relational contract structures, a condition exacerbated by their over-reliance on star players. Second, and perhaps most important, integration forced the Negro Leagues to compete in a market dominated by the monopoly power of the Major Leagues. By 1922, perhaps earlier, the Major Leagues had acquired a monopoly over the market for White professional baseball players in the United States through its reserve system. Thereafter, the Major Leagues strengthened that monopoly with the development of Branch Rickey's other great innovation: the development of the minor leagues as the farm system for the Major Leagues. Finally, the owners of the Negro Leagues appear to have accepted the inevitability of extinction.

This article first describes the relational contract structures of the Negro Leagues. Second, it examines the possible circumstances under which the Negro Leagues or some remnant could have survived after the integration of the player market. Third, the article describes how the Major Leagues acquired and maintained a monopoly over the market for White professional players through the reserve system, and the subsequent inclusion of Black players. That part further explains how the use of that monopoly power destroyed the Negro Leagues. Finally, the article discusses various legal strategies that the Negro Leagues could have used in trying to survive.

\section{RELATIONAL CONTRACTS IN THE NEGRo LEAGUES}

Several books have been written about the Negro Leagues and their players. These books provide much of the memorialized history of the formation and operation of the leagues. The term "Negro Leagues" often is used rather loosely to refer to teams of Black professional players with mostly Black owners operating in the United States between 1880 and 1955. The term is used here to refer to the formal leagues, particularly the Negro American and National Leagues. ${ }^{2}$ Most Negro teams operated independently and were not affiliated with a formal league. ${ }^{3}$ The earliest teams engaged in barnstorming sport. ${ }^{4}$ The teams traveled the country playing local teams, both Black and White. Many combined showmanship with the game to boost attendance. ${ }^{5}$ Frequently, the games were significant social events in Black communities. Even those teams that were members of formal leagues barnstormed before, during

${ }^{2}$ Teams of the Negro Leagues, (updated May 28, 1996) <http://www.nc5.infi.net/-moxie /nlb/teams/teams.html >.

${ }^{3}$ Id.

4 Phil Dixon, The Negro Basebatll Leagues: A Photographic history 20-23 (1994).

${ }^{5}$ Id. at 18. 
and after joining leagues. The Kansas City Monarchs, who introduced night baseball in $1930,{ }^{6}$ and the Indianapolis Clowns were two of the most successful barnstorming teams. ${ }^{7}$

Any business firm, in order to be successful, needs continuous relationships with employees, suppliers, landlords, financiers and owners. In the American economy, these relationships are reflected in various contractual arrangements that have been described as "relational contracts," because they provide for or establish a framework for a set of transactions over time. ${ }^{8}$ Professional baseball, whether involving barnstorming or otherwise, requires relational contracts with other teams and arena owners, financiers and players. Contrary to popular connotations, the relational contract structure of the barnstorming operations of Negro teams was quite organized. Arrangements among teams and facility operators were made through a system of booking agents at least one year in advance. ${ }^{9}$

The reliability of the booking agent system, however, did not mean that the arrangements were not costly. For Negro teams, scheduling of barnstorming games posed other problems. The teams confronted obstacles in obtaining suitable playing facilities. In Modern Amusements, Inc. v. New Orleans Public Service, Inc. ${ }^{10}$ for example, a booking agent arranged for games between two Negro teams with the lessee of a baseball park. A fight occurred during the first game which required police involvement. The park was located in a White neighborhood and the lessor responded to the altercation by invoking a clause in the lease requiring the lessee to observe "all rules and regulations prescribed by the lessor. ${ }^{11}$ Specifically, the lessor issued a regulation prohibiting any more games in the park between Negro teams. The court upheld the regulation but explained:

But, considering that the park was in a neighborhood of residences occupied by White families, and considering that the first and only game of Negro baseball played in the park brought on a fight and a disturbance of the peace, and considering that the lessor, being a public service corporation, was necessarily solicitous of the good will of the public, our opinion is that the proscribing of Negro baseball games in Kempster Park at night was not an unreasonable rule or regulation. ${ }^{12}$

'Id. at 149-51. They carried a portable lighting system with them.

${ }^{7}$ Id. at 20.

- Charles J. Goetz \& Robert E. Scott, Principles of Relational Contracts, 67 VA. L. REv. 1089,1091 (1981).

Dxon, supra note 4, at 23.

${ }^{10} 165$ So. 137 (La. 1935).

"Id. at 139.

${ }^{12}$ Id. at $139-40$. 
Some teams rented Major League stadiums for their own games and played when the Major League team was not in town. The use of facilities by Negro teams also surfaced in a rent dispute between the St. Louis Cardinals and their landlord. The Cardinals unsuccessfully asserted that they were entitled to an offset for the use of the lighting system jointly owned by the Cardinals and the St. Louis Browns during "Negro exhibition games."13 The likely ultimate effect was an increase in the rent charged to Negro teams. The practice of renting Major League facilities continued after the Negro League era. Some teams apparently constructed and owned their own facilities. ${ }^{14}$

Not only did Negro teams have to face arenas which were off limits due to stereotypical fears, ${ }^{15}$ they also had to find places to play with segregated seating. Satchel Paige refused to pitch in the Kansas City stadium unless the segregated seating restrictions were removed during Negro League games. ${ }^{16}$ Players also encountered segregated accommodations while traveling. ${ }^{17}$ Teams also faced tort liability from which White clubs were not immune. ${ }^{18}$ In some cases, however, the lawsuits were filed against the owners or regular lessee of the parks. Even though the teams may not have been sued, such suits no doubt raised the cost of renting stadiums for them. Consequently, Negro League teams faced the daunting task of playing numerous away games to increase revenue and incurring additional costs in the process. The additional costs left less money to pay the players to compete in an integrated players' market.

Despite the profitability of barnstorming, it did not offer the quality of product and growth potential of league sport. This observation is amply demonstrated by the history of the Harlem Globetrotters. ${ }^{19}$

${ }^{13}$ Dodier Realty \& Inv. Co. v. St. Louis Nat'l Baseball Club, Inc., 238 S.W.2d 321, 325 (Mo. 1951).

${ }^{14}$ The Memphis Red Sox owned their stadium, Martin Park, but were one of the few teams to do so. Teams of the Negro Leagues, supra note 3. See also Frisby v. Grayson, 63 So.2d 96 (Miss. 1953) (dispute invalving the construction of ballpark for Blacks).

${ }^{15}$ See Dudley v. City of Charlotte, 27 S.E.2d 732 (N.C. 1943) (unsuccessful action to enjoin the City of Charlotte from maintaining a recreational park for Negroes on property near a White neighborhood).

${ }^{16}$ DixoN, supra note 4 , at 197.

${ }^{17} \mathrm{Id}$. at 164

${ }^{18}$ See, e.g., Leek v. Tacoma Baseball Club, Inc, 229 P.2d 329 (Wash. 1951) (suit brought by fan hit by ball hit over protective netting in game involving Kansas City Monarchs); Salevan v. Wilmington Park, Inc., 72 A.2d 239 (Del. Super. Ct. 1950) (suit brought by bypasser struck by baseball leaving the park). For a similar case involving the Harlem Globetrotters, see McFatridge v. Harlem Globe Trotters, 365 P.2d 918 (N.M. 1961).

${ }^{10}$ See infra notes 61-68 and accompanying text (describing early days of the Harlem Globetrotters). 
Although league sport does involve teams traveling across the country, ${ }^{20}$ league sport is a very different product.

The product of a sports league is not merely a series of isolated games unrelated to one another. The NFL, for example, produces an annual series of interrelated football games involving all of its twenty-eight member clubs, annual division championship races, a nine-game postseason playoff tournament, and ultimately a Super Bowl game and league champion. ${ }^{21}$

One court described league sport in the context of professional baseball similarly:

The function of each league was to regulate contests between teams representing the several clubs in the league, which compete annually for championship [sic]. . . . The club which wins the championship pennant in any year in one major league competes for the world's championship in that year with the winner of the pennant in the other. $^{22}$

League sport involves stronger relational contracts among teams and arena owners than barnstorming. As reflected in David Wyatt's famous call for Negro league sport on a national basis, it also leads to stronger relational contracts with fans. ${ }^{23}$

${ }^{20}$ Federal Baseball Club v. National League of Profl Baseball Clubs, 259 U.S. 200, 208 (1922), affg 269 F. 681 (D.C. Cir. 1920).

${ }^{21}$ Gary R. Roberts, Sports Leagues and the Sherman Act: The Use and Abuse of Section 1 to Regulate Restraints on Intraleague Rivalry, 32 U.C.L.A. L. REv. 219, 229 (1984).

${ }^{22}$ Federal Baseball, 269 F. at 683.

${ }^{23}$ We have players who can bat and players who can field. We have players who can pitch and who can run, we have magnates with the glad hand, also the baseball fan; we have coaches who can make a lot of fun. We have umpires, we have scribes, the latter to criticize; we have cranks and also enthusiasts; but of all this, the one we need most is the man who will say, 'Let's organize.'

Big leagues all have grounds and players of wide renown; they have their Wagners and their Crawfords and their Stahls; they have magnates with money to burn and others eager to earn. They are organized and that's the best of all. They've got us on the run in this game, more work than fun. This fact, no doubt you have surmised, so while running in this race, why not keep up with the pace? Get together and proceed to organize.

The importance of this plea sooner or later you'll surely see, that it's timely and directed at the right place; so while you have the chance, accept opportunities to advance and uphold the rapid progress of our race. The game is honest, the game is square, a point we all declare, so we need not dwell on that at any length; from out of our slumber let us arise and treat our friends to a grand surprise-be up and doing! Let's organize.

David Wyatt poem "Let's Organize" in the March 5, 1910 FrEEMAN, quoted in DrXoN, supra note 4, at 104-5. 
The most significant proponent of Negro league sport was Rube Foster, the founder of the Chicago American Giants. He ultimately persuaded other owners to form the Negro National League in $1920{ }^{24}$ They also formed a governing body called the National Association of Colored Professional Baseball Clubs. ${ }^{25}$ League play meant league competition, with games against other league members resulting in a championship. The Eastern Colored League was formed in 1923 and disbanded in $1928 .{ }^{26}$ The Negro National League suffered financially during the Depression Era, failed in $1932,{ }^{27}$ and was revived by Gus Greenlee in 1933. ${ }^{28}$ The Negro American League was founded in 1937 by J.B. Martin. ${ }^{29}$ The Negro National League engaged in the Negro World Series and all-star games with the Eastern Colored League and the Negro American League. There were numerous other leagues, including the Negro Southern League.

Although the Negro Leagues provided organization, they lacked strong relational contract structures. ${ }^{30}$ The production of league sport requires two distinct layers of relational contracts. ${ }^{31}$ First, team owners must associate to form the league, establish league objectives and design the league product. Each owner then must enter into a second layer of contracts with players, stadium landlords, financiers and suppliers. In the league, each team owner is subject to the viability of the second layer of contracts of other team owners. This structure contrasts with barnstorming sport, under which the first layer was established through booking agents, and individual teams were not dependent upon the second layer structures of other teams. If a team failed, a barnstorming team could simply line up another team through the booking agent.

The relational contracts among owners were weak in the Negro Leagues. Teams were not committed exclusively to playing in the league, but continued to engage in barnstorming with non-league teams as gate receipts provided the largest source of revenue. ${ }^{32}$ The

24 DxON, supra note 4, at 123.

${ }^{25}$ Id. at 124.

${ }^{25} I d$, at 21 .

${ }^{27}$ Id. at 151 .

${ }^{28}$ Id. at 158-59. The governing organization was named the National Association of Professional Baseball Clubs, which was identical to the governing organization of the White minor leagues.

29 Teams of the Negro Leagues, supra note 2.

${ }^{30}$ See supra note 8 and accompanying text (describing principles of relational contracts).

${ }^{31}$ See Alfred D. Mathewson, Intercollegiate Athletics and the Assignment of Legal Rights, 39 ST. LoUS U. L.J. 39, 39-40 (1990) (explaining relational contracts in a collegiate sports context).

${ }^{32}$ Geoffrey C. WARD, Ken BURNS \& JIM O'CoNNOR, Shadow BaLl: A History of THE NeGRo LEAGUES 15 (1994). 
barnstorming operations thus served as a hedge against the risk that other league teams would fail. Accordingly, individual teams needed to schedule as many games as possible, and league games comprised only a fraction of the total games each team played. ${ }^{33}$ The result was that each team played a different number of games. Because team owners were unable to rely on the league's economic structure for financial success, the associational glue was not strong and owners moved in and out of leagues at will..$^{34}$

Relational contracts between teams and players were even more problematic. In Major League Baseball, star power and team synergy were essential ingredients of the league product marketed to the public. The American and National Leagues offered competitions among teams of professional ballplayers. They cultivated team personalities and developed fan loyalty. Murderers' Row, the Gas House Gang and the Bronx Bombers are all too familiar monikers for team personas. The importance of star appeal and team synergy was pivotal in the landmark case of Philadelphia Ball Club v. Lajoie. ${ }^{35}$ In that case, Napoleon Lajoie, a great White player, entered into a contract with a Cleveland team while under contract with a Philadelphia team. Cleveland offered him more money. The Philadelphia team sought an injunction prohibiting him from playing for Cleveland. Its argument was based on his value to the team. That value was based on two things: his star appeal and his importance to team synergy.

[Lajoie] is an expert baseball player in any position; ... he has a great reputation as a second baseman; ... that his withdrawal from the team ... would probably make a difference in the size of the audiences attending the game.... He has been for several years in the service of the plaintiff club.... He has become thoroughly familiar with the action and methods of the other players in the club, and his own work is peculiarly meritorious as an integral part of the team work which is so essential. ... Lajoie is well known, and has great reputation among the patrons of the sport, for ability in the position which he filled, and was thus a most attractive drawing card for the public. He may not be the sun in the baseball firmament, but he is certainly a bright particular star. ${ }^{36}$

The Major Leagues suppressed the price of that value through an extremely strong employment contract structure in the form of its legally protected reserve system.

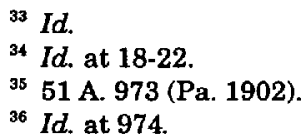


The historical record shows the substantial reliance of the Negro Leagues on the star power of players such as the incomparable Satchel Paige, Josh Gibson, James "Cool Papa" Bell, Oscar Charleston and Judy Johnson. The significance of star power is amply demonstrated by the relative popularity of the Negro Leagues' annual all-star game compared to their World Series. The All-Star game always outdrew The World Series. ${ }^{37}$ The only plausible explanation for that popularity differential is that the All-Star game showcased numerous stars whereas the World Series featured only the handful of stars found on the two competing teams. The historical record also shows not only the inability of Negro League teams to afford team synergy, but an extremely weak employment contract system. Not only did the Negro Leagues not have a reserve system, but written player contracts were the exception rather than the rule. A team that became successful and developed its players into stars was sure to lose them. Accordingly, the Negro Leagues featured true unrestricted free agency. A star was able to sell his services to the highest bidder anywhere. ${ }^{38}$ When the Negro League season ended, players went south to the Mexican League and to the Dominican League, where they were welcomed with open arms.

The free agency system in the Negro Leagues was consistent with a cultural value disfavoring limitations on the freedom of individuals to choose their employers. ${ }^{39}$ This cultural value was at the heart of Curt Flood's challenge to the reserve system. ${ }^{40}$ In addition to the antitrust claim on which the Supreme Court and the lower courts decided the case, Flood alleged that Major League Baseball's reserve system violated the Thirteenth Amendment's prohibition against involuntary servitude. ${ }^{41}$ The legal claim was founded upon a statement in Pollock $v$. Williams, ${ }^{42}$ that the "undoubted aim of the Thirteenth Amendment ... was not merely to end slavery but to maintain a system of completely free and voluntary labor throughout the United States." ${ }^{43}$ Professional baseball players subject to the reserve system could not provide their

${ }^{37}$ Dixon, supra note 4, at 20.

${ }^{38}$ Satchel Paige has been described as a notorious free agent, even when under contract. DxXoN, supra note 4 at 168-74. Josh Gibson also took advantage of the true free agency that existed in the Negro Leagues. JOHN B. HOLWAY, JOSH GIBSON 61 (1995). Notwithstanding the free agency that existed, player salaries were lower than those in the Major Leagues. DixoN, supra note 4, at 241.

${ }^{39}$ See generally Anthony R. Chase, Race, Culture and Contract Law: From the Cottonfield to the Courtroom, 28 CoNN. L. REv. 1 (1995) (describing African-American attitudes toward contractual limitations on employment).

${ }^{40}$ See Flood v. Kuhn, 407 U.S. 258 (1972) (listing Flood's challenges to Major League Baseball's reserve system).

${ }^{41} I d$. at $265-66$.

42322 U.S. 4 (1944).

${ }^{43}$ Id. at 17 . 
services freely to the employer of their choice. Most players entered the industry through the player draft pursuant to which Major League teams picked players who were not yet under contract to any team. Once a player was drafted, he could contract to play only for that team or for a team to whom the drafting team assigned its rights. The player could not unilaterally choose to play for any other team. A player who avoided the draft could contract with the team of his choice, but once he signed, he could play only for that team or a team to whom his contract was subsequently assigned. The reserve system thus obviated the right of the player to choose his employer. It was this condition that Curt Flood found so unacceptably onerous that he was willing to give up an annual salary of $\$ 100,000$ per year and his career in professional baseball.

The cultural attitude was reflected in Jackie Robinson's testimony before the Senate Subcommittee on Antitrust and Monopoly of the Committee on the Judiciary in 1958. Six star players appeared before the Subcommittee, but Robinson was the only one who criticized the reserve system.

I think they [players] should in some way be able to express themselves as to whether or not they want to play for a certain ball club. I am highly in favor of the reserve clause. I do not want to get this out that I don't believe there should be some control. But on the other hand, I don't think the owners should have all of the control. I think that there should be something that a ballplayer himself could say that would have some effect upon his particular position with a ball club. $^{44}$

Robinson's concern was that the reserve system prevented players who were not stars from exercising choice so as to better their careers and value. ${ }^{45}$

Cultural attitudes on the freedom of workers to choose their employer also were reflected in the actions of Negro League owners once the Major Leagues started signing Black players. The owners of the Negro League teams were confronted with a quandary. On one hand, they did not want to stand in the way of the freedom of their players to better themselves, but on the other, they were fighting for their survival. Until the Robinson signing, the Negro Leagues lacked a reserve system. $^{46}$ In fact, many teams did not use written contracts until after Branch Rickey refused to pay compensation to the Kansas City

44 Hearings Before the Senate Subcommittee on Antitrust and Monopoly of the Committee on the Judiciary, 85th Cong., 2d Sess. 295 (1958) [hereinafter Hearings] (statement of Jackie Robinson, formerly with the Brooklyn Dodgers).

${ }^{45}$ Id. at 296.

${ }^{46}$ Dixon, supra note 4 , at 88. 
Monarchs after signing Jackie Robinson. ${ }^{47}$ J. L. Wilkinson, the owner of the Kansas City Monarchs, was famous for his handshake contracts, and Rickey cited the lack of a written contract as a reason for refusing to pay. He also cited the well known ties of several Negro League owners to the numbers racket. ${ }^{48}$

In another famous incident, Effa Manley, the owner of the Newark Eagles, demanded compensation from the Dodgers, who wanted to sign Monte Irvin who was bound by a written contract. ${ }^{49}$ Rickey responded by criticizing her publicly for standing in the way of the player. ${ }^{50}$ She refused to back down and received compensation. ${ }^{51}$ Thereafter, the Negro Leagues required a uniform player contract so that teams could receive compensation when their players were signed by Major League teams. The uniform player contract was thus not used to stifle player choice, but to obtain compensation from the Major Leagues for the loss of a talented player. The Major Leagues eventually avoided the cost of buyouts from Negro League teams by recruiting Black players out of high school. ${ }^{52}$

One advantage of a league is the centralized scheduling of league games. ${ }^{53}$ It is a league expense paid by member clubs in some fashion. The Office of the Commissioner of Major League Baseball is funded by the Major League teams and one of its more thankless responsibilities is scheduling. ${ }^{54}$ The Negro Leagues, however, continued to use the booking agent system. When Rube Foster organized the Negro Leagues, he attempted to centralize this function and served as booking agent for the League for a controversial five percent fee. ${ }^{55}$

In addition to the weak contracts among owners, associational contracts among owners and the employment contracts with players, financial relationships provided limited access to capital resources. Some owners were individuals, like Bill "Bojangles" Robinson, who became wealthy from other business endeavors. Several owners had ties to the numbers racket. ${ }^{56}$ At least one club tried raising funds through

\footnotetext{
${ }^{47}$ Id. at 287.

ad James Bankes, The PitTsburgh Crawfords: The Lives and Times of Black BASEBALL'S MOST EXCITING TEAM! $91-99$ (1991).

${ }^{49}$ DIXON, supra note 4, at 305-6.

${ }^{30}$ Id. at 306 .

${ }^{51}$ Id.

${ }^{52}$ BANKES, supra note 48 , at 143.

${ }^{53}$ Federal Baseball Club v. National League of Prof'l Baseball Clubs, 269 F. 681, 683 (D.C. Cir. 1920), affd 259 U.S. 200 (1922).

${ }^{54}$ Steve McClellan, Cubs Balk at Vincent Move; Team Owner Tribune Files Suit to Block Division Switch, BROADCASTING, July 13, 1992, at 10.

${ }^{\text {Bs }}$ Dixon, supra note 4, at 99.

${ }^{56}$ Kenneth L. Shropshire, Diversity, Racism, and Professional Sports Franchise Ownership: Change Must Come from Within, 67 U. CoLO. L. REv. 47, 65 (1996).
} 
a securities offering. ${ }^{57}$ With limited financial resources, most owners could not afford team synergy, and encountered difficulty in retaining stars as their compensation increased each year. During World War II, the Negro Leagues thrived even though many of its stars served in the military. Increased popularity meant higher gate receipts, which in turn meant higher salaries for their players, especially the stars. In 1944 , Satchel Paige, with a salary of $\$ 40,000$ per year, was the highest paid player in baseball. ${ }^{58}$

Although the weak relational contract structures of Negro League teams made their success more difficult than that for White Major League teams, those obstacles seem indistinguishable from those confronting other Black institutions which survived integration. Black colleges and universities faced similar obstacles, and the experience of the ATA would not be expected to have been any different either. Accordingly, the resulting competitive position of the leagues does not sufficiently explain their extinction.

THE POSSIBILITY OF SURVIVAL

\section{The American Tennis Association and Black Colleges}

The extinction of the Negro Leagues in the post-integration era was consistent with the theories of some scholars of Black capitalism, most notably Andrew Brimmer, a former member of the Federal Reserve Board of Governors and now the chairman of the District of Columbia Financial Control Board. According to Brimmer, many Black firms benefited from, and indeed preferred, segregation because of the absence of competition from White firms. ${ }^{59}$ Although White fans attended Negro League games, the teams faced virtually no competition from White firms in the market for Black baseball players. Brimmer's theory would predict that the Negro League teams would fail once better financed White firms, i.e., Major League Baseball teams, began competing in that market. The theory appears to predict the failure of the Negro Leagues as well.

Brimmer's theory, however, only explains the preference for segregated markets by Black-owned firms; it leads to the conclusion but does not explicitly hold that the demise of Black firms is an inevitable consequence of the integration of previously segregated Black markets. In fact, it explains the extinction of the Negro Leagues only if Black firms made no competitive response or any such response was doomed

${ }^{57}$ Dixon, supra note 4, at 84.

${ }^{38}$ Id. at 193 .

${ }^{59}$ Andrew F. Brimmer, The Negro in the National Economy, in THE AMERICAN NEgRo REFERENCE BOOK 251, 291-92 (John Davis, ed., 1966). 
to be inadequate. The experience of other Black sports organizations in the post-integration era suggests that integration alone is not a sufficient explanation of the demise of the Negro Leagues or Blackowned teams.

The American Tennis Association is a case in point. The ATA was founded in 1916 as the Black counterpart of the United States Lawn Tennis Association. ${ }^{60}$ All the great Black tennis stars, including Arthur Ashe and Althea Gibson, were nurtured in its tournaments. It has continued to thrive in the post-integration era. It still holds an annual national championship and many of today's Black stars earn their spurs there.

One reason the ATA may have survived, apart from the support of the civil rights community, is that it has had a continuing role in the nurturing and development of future African-American stars. Its programs expose African-Americans in urban areas and elsewhere to the game of tennis often using public facilities. Even Motown was assured a continuing place in the music industry firmament by access to young stars. The ATA also has another feature which it shares with historically Black colleges. Its programs are frequently tied to definable African-American communities. Historically Black colleges and universities may be viewed as extensions of the communities from which their African-American students come, or a representation of a national community.

\section{Abe Saperstein and the Globetrotters}

Negro League teams were not the only professional sports organization featuring Black talent whose future was threatened in the post-integration era. The Harlem Globetrotters, although not Blackowned, offered the most prominent professional opportunity for Black basketball players until the Basketball Association of America, the forerunner of the National Basketball Association (NBA), integrated its player ranks in 1946. ${ }^{61}$ Arthur Ashe characterized the position of the Globetrotters in the market for Black professional basketball players in the early 1940 s as a monopoly. This characterization, while inaccurate, comes close to describing their domination of that market. Unlike would-be owners of Major League franchises who failed to exploit the market of Black professional baseball players, Abe Saperstein acquired that market position by taking advantage of the bigotry of other White team owners who refused to deal with Black players.

${ }^{60}$ Eric L. Smith, A.T.A. Junior Development Program, BlACk ENTERPRise, Sept. 1995, at 115 .

${ }^{61}$ ARTHUR R. AShe, JR., A HaRd ROAD to GLORY: A HiStory OF THE AFRICAN-AMERICAN ATHLETE SNNCE 1946, at 52 (1988). 
However, the Globetrotters engaged in barnstorming and did not belong to a league. They made their money traveling the country and playing 150 to 170 games over a six to seven month season. ${ }^{62}$ Without significant league sport competition, the Globetrotters became the most popular professional basketball team in the world. The market position of the Globetrotters was threatened by the racial enlightenment of the owners of the NBA and its predecessors. The Globetrotters' domination of the market for professional Black players was over; they would now have to compete for the best players in that market. Indeed, the survival of the Globetrotters was jeopardized because much of their success was built upon a shortage in the supply of Black professional players resulting from their exclusion from white-owned teams. The advent of their inclusion on teams engaged in league sport led to an enhancement of the quality of the league product and an increase in the supply of quality professional basketball product.

As the NBA's league sport gained in popularity, the fortunes of the Globetrotters declined. ${ }^{63}$ Abe Saperstein, the then owner of the Globetrotters responded to this challenge initially by cultivating a relationship with the NBA. ${ }^{64}$ In the early days of the NBA, the Globetrotters helped the league survive by scheduling games against NBA teams or in conjunction with their games. ${ }^{65}$ He also owned an interest in the Philadelphia Warriors, but that relationship soured after the Globetrotters defeated the Minneapolis Lakers and the NBA adopted an informal rule prohibiting member teams from playing the Globetrotters. ${ }^{66}$ Saperstein and the NBA also had disagreements over his contributions to the NBA and game rules. The survival of the Globetrotters was jeopardized by the difficulty of retaining access to arenas in NBA cities and stiff competition for the best players.

Saperstein appears to have believed that the survival and success of the Globetrotters depended upon a symbiotic relationship with a professional league. ${ }^{67} \mathrm{He}$ responded by founding the American Basketball League (ABL) as a rival to the NBA. ${ }^{68}$ Although some Globetrotters were allowed to play in the new league, Saperstein did not cause the Globetrotters to become a team in the league.

The ABL failed, but more because of inadequate financing than due to the efforts of the NBA. Saperstein's hybrid league strategy thus failed because of the inability of his collaborators to obtain suitable

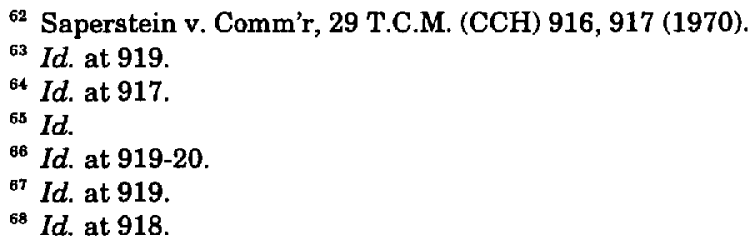


relational contracts with other investors or financiers. The strategy had some chance to succeed because unlike the Negro Leagues, neither the Globetrotters nor the ABL confronted an NBA monopoly over the business of professional basketball or the market for professional players. In fact, the ABL was subsequently revived as the American Basketball Association, which ultimately merged with the NBA. The Globetrotters appear to have survived because of another strategy with which Abe Saperstein is more commonly associated. He changed the game product of the Globetrotters from entertaining with a highly competitive basketball game to one involving the display of highly refined basketball skills and clowning. It was a strategy pursued by the Indianapolis Clowns that ultimately failed. Nevertheless, this product alteration appears to have been the strategy that most accounts for the survival of the Globetrotters. Today, they are the dominant supplier of this product and are Black-owned.

\section{Black High School Athletic Associations}

The case of Black high school athletic associations provides an example of Black institutions determined to survive integration in some fashion. The Virginia Interscholastic Association was formed by Black high schools apparently after Brown v. Board of Education was decided. ${ }^{69}$ The organizers explicitly formed it to provide leverage to gain admittance to the all-White Virginia High School League (VHSL). ${ }^{70}$ One by one, its members joined the VHSL and in 1969, the two organizations merged. ${ }^{71}$ The association ceased to exist as an all-Black organization, but its members entered the White league as equals. In other states, efforts of Black high schools to attain membership in, or Black high school leagues to merge with White interscholastic associations resulted in litigation. ${ }^{72}$

Some Black high schools pursued the survival of their sports programs through a civil rights litigation strategy. In St. Augustine, a high school with an all-Black student body sought admission to the Louisiana High School Athletic Association (LHSAA), then comprised of high schools with integrated but formerly all-White student bodies. St. Augustine High School was a member of the Louisiana Interscholastic

${ }^{69}$ Tom Robinson, A League of Their Own, VirginIAN-PILOT AND LEDGER-STAR, Feb. 22, 1993, at C1. The VIA succeeded the Virginia Interscholastic Athletic League, which had been formed in 1925 to govern only sports. The new association covered music and drama as well. Id.

${ }^{70} \mathrm{Id}$.

${ }^{71} I d$.

${ }^{72}$ See, e.g., Louisiana High Sch. Athletic Ass'n v. St. Augustine High Sch., 396 F.2d 224 (5th Cir. 1968) (effort to merge black and white athletic leagues); Lee v. Macon County Bd. of Educ., 283 F. Supp. 194 (M.D. Ala. 1968) (same). 
Athletic and Literary Organization (LIALO), which was organized to coordinate the interscholastic activities of Black high schools. ${ }^{73}$ The comparison of the LIALO to the LHSAA was akin to that between the Negro Leagues and the Major Leagues. Prior to the application, no Negro high school had ever applied for membership in the LHSAA. ${ }^{74}$ The LHSAA responded by amending its constitution to require the vote of two-thirds of its membership to admit a new member instead of the approval of its executive board. The LIALO did not seek a merger but St. Augustine High School successfully challenged its exclusion on equal protection grounds. $^{75}$

In Lee v. Macon County Board of Education, the plaintiffs challenged the practice of scheduling interscholastic athletic contests only among schools within racially designated athletic associations. ${ }^{76}$ The Alabama High School Athletic Association was comprised only of White schools and the Alabama Interscholastic Athletic Association was comprised of Black schools. Both associations had promulgated rules prohibiting its members from playing schools in the other association. The court found that the segregation of athletic activities discriminated against Black schools. ${ }^{77}$ Moreover, it found that the desegregation that had occurred by admitting Black athletes who had exercised their freedom of choice to play in the White association did not amount to desegregation. ${ }^{78}$

Again, the parallels between the relationship of the Black high school association and the White association to that of the Negro Leagues and the Major Leagues is substantial. The court held that the unification of the two athletic associations by merger was required. ${ }^{79}$ The court went on to specify guidelines for the terms of the merger. Among others, it stated that if the Black association was abolished as a result of the merger, its executive director or its designee should be made an

${ }^{73}$ St. Augustine, 396 F.2d, at 225.

${ }^{74}$ Id. at 226.

${ }^{75} \mathrm{Id}$. at 228-29.

${ }^{76}$ Macon County, 283 F. Supp. at 196-97.

${ }^{77}$ The court described the effects as follows:

Alabama's dual athletic system has led to inadequate athletic programs in the various Negro schools. The Negro athletic association has not participated in the statewide tournaments and contests that are the prime source of revenue for the White athletic association. ... This has resulted in inadequate financing of the athletic programs for the Negro schools. The dual system has resulted in a loss of recognition for athletes in the Negro schools-loss of recognition on both local and national levels. The National Federation of High School Athletic Associations recognizes only one association in Alabama: the Alabama High School Athletic Association.

Id. at 197 .

${ }^{78}$ Id.

${ }^{79}$ Id. at 198. 
executive officer of the new association. ${ }^{80}$ It further specified that the administrative staff should be desegregated such that both associations held a significant number of positions on the governing board ${ }^{81}$

The Black high school experience is interesting because the parallels of their experience to the relationship between the Negro Leagues and the Major Leagues are so strong. Segregated Black high school sports existed because of the exclusion of Black students from White schools. Black school sports faced the same danger of extinction as the Negro Leagues, but the civil rights litigation strategy contemplated the integration of institutions as well as student athletics. That strategy indicates that the concept of merger between Black and White sports organizations existed in the civil rights community even as the Negro Leagues faded into extinction. Perhaps, even if the Negro Leagues could not have survived as an independent league, Macon County suggests that one or more of their members-Black-owned teams-could have joined or been made a part of the Major Leagues. The possibility of a Negro League or Black-owned team joining the Major or minor leagues, however, does not appear to have been considered seriously since the Pythian Club was denied entry into a league comprised of White teams in $1868 .^{82}$

The record is unclear about the thinking in the White world on the inclusion of the Negro League teams in leagues with White teams. Branch Rickey, for example, formed a club called the Brooklyn Brown Dodgers, which joined the United States Baseball League that Gus Greenlee organized after he left the Negro National League. It is widely believed that Rickey used the club as a subterfuge to scout Black players in anticipation of breaking the color barrier in the Major Leagues. ${ }^{83}$ The USBL only lasted two months and there has been speculation about Rickey's true purpose. ${ }^{84}$

Other than Branch Rickey's failed experiment with the USBL, there does not appear to be any indication of the Major Leagues' interest in integrating ownership. The lack of discussion was reflected in Commissioner Frick's testimony before Congress in 1958 on Major League Baseball's decision to permit the New York Giants and the Brooklyn Dodgers to relocate to the West Coast in 1956:

Senator O'Mahoney: You were anxious to get Major League teams to the West Coast. My question was, why did you not do it by creating new teams?

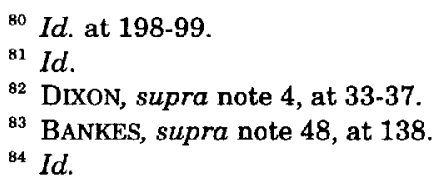


Mr. Frick: We have no other clubs that wanted to come in, we had no club that wanted to be created... When the time comes, to ... expand the league, it seems to me entirely proper that ... the people who have put their money in baseball in the minor league operation should be entitled to have that club, not some other body come in from outside. ${ }^{85}$

It is clear that the reference to the minor league operation "did not include the Negro Leagues." ${ }^{36}$

The history of the Globetrotters may be illuminating on the interest of White owners in integrating Black teams into White leagues. One of the unanswered enigmas is why the Globetrotters did not become a team in the NBA or the ABL. Abe Saperstein did enjoy relational contracts with NBA team owners in the early years. The NBA managed to survive in the early years by arrangements between NBA owners and Sapertstein to schedule Globetrotter games in conjunction with NBA games. ${ }^{87}$ The quid pro quo for Saperstein was the access of the Globetrotters to large arenas in NBA cities. Saperstein did, in fact, seek a franchise in the NBA. His estate maintained in Tax Court proceedings that his quest was unsuccessful because NBA owners insisted on a $\$ 250,000$ franchise fee and he was unwilling to pay it. ${ }^{88}$

The court opinion implies that he intended to maintain the Globetrotters as an independent organization and did not intend to make the Globetrotters a league team. But why not? If the Globetrotters could draw fans to NBA games by appearing on the same bill, would not their inclusion as a league member have strengthened the NBA? The question is raised again with the formation of the ABL. Saperstein, as its Commissioner, assigned some Globetrotter players to ABL teams, but again indicated that he intended to maintain the Globetrotters as an independent organization. The court did express disbelief at the assertion of the estate that he wanted to develop the $\mathrm{ABL}$ as a farm league for the development of talent for the Globetrotters That disbelief rested on the court's view that such a relational contract was impractical.

The question remains. Were the Globetrotters excluded from these leagues because of an unwillingness of White owners to include a team comprised solely of Black players? If the position of his estate is accepted, the answer is no. Given the racial norms of the era, it is plausible that race did play a significant role. If the Globetrotters were

${ }^{85}$ Hearings, supra note 44, at 172 (testimony of Ford Frick, then Commissioner of Major League Baseball). Mr. Frick was responding to questions about the moving of the Brooklyn Dodgers and the New York Giants to the West coast.

${ }^{86}$ See infra notes 92-114 and accompanying text (describing baseball's reserve system and monopoly power).

${ }^{87}$ Saperstein v. Comm'r, 29 T.C.M. (CCH) 916, 920 (1970).

${ }^{89}$ Id. at 920 . 
not able to obtain a seat at the league table, how much more difficult would it have been in baseball? In any event, there appears to have been little interest on the part of the civil rights community to come to the aid of Negro League teams or their owners, whatever the motivations of Major League owners. ${ }^{89}$ There was, however, such interest when it came to tennis. ${ }^{90}$ Even if such interest had existed, no civil rights law existed that protected Black business owners from racial discrimination in business dealings. ${ }^{91}$

If survival of the Negro Leagues as a minor league or the entry of one or more Negro League teams were possible after integration, why did the leagues and the teams become extinct? The most likely culprit appears to have been the monopoly power of Major League Baseball.

\section{The Reserve System and Monopoly Power}

By 1914, at least one court had recognized that the Major Leagues had obtained a monopoly over the market for White professional players via the reserve system. In American League Baseball Club of Chicago $v$. Chase, ${ }^{92}$ a player signed a contract with a team in the Federal League while under contract to the Chicago White Sox of the American League. The court found that the Major Leagues had a monopoly over the business of baseball and refused to uphold an injunction preventing the player from playing for the Federal League team. The court stated that it would not assist in enforcing an agreement that was a "part of a general plan having for its object the maintenance of a monopoly, interference with the personal liberty of a citizen, and the control of his free right to labor wherever and for whom he pleases, and [would] not extend its aid to further the purposes and practices of an unlawful combination. ${ }^{n 93}$

The monopoly referred to in Chase was obtained through Major League Baseball's infamous reserve system, initially introduced in $1887 .^{94}$ The reserve system was implemented through a series of clauses in the Uniform Player Contract and the Major League Rules. The Major League Rules imposed several limits on the right of individual clubs to contract with players. These rules required individual clubs to use a uniform player contract and prohibited them from including a

${ }^{89}$ Arthur Ashe noted that the civil rights movement was very active in pressuring the Major Leagues to take Black players. ASHE, supra note 61 , at 9 . But he also pointed out that the NAACP itself was generally silent when it came to baseball. Id. at 57-64.

go Id. at 160.

91 Robert E. Suggs, Racial Discrimination in Business Transactions, 42 HASTINGS L.J. 1257,1263 (1991).

92149 N.Y.S. 6 (1914).

${ }^{93}$ Id. at 20.

${ }^{94}$ Flood v. Kuhn, 407 U.S. 258, 259 n.1 (1972). 
nonreserve clause..$^{95}$ They prohibited individual clubs from tampering, i.e., negotiating, contracting or dealing with a player under contract to another member of the National or American Leagues. ${ }^{96}$ They prohibited individual teams from contracting with a player who had been blacklisted, i.e., declared ineligible, for violating the reserve system. ${ }^{97}$ The Uniform Player Contract imposed restrictions on players. The UPC gave the team the right to enjoin the player from playing for any other team during the term of the contract. ${ }^{98}$ It contained what the teams construed as a perpetual renewal clause, thereby expanding the term of the contract in perpetuity. ${ }^{99}$ The UPC and Major League Rules provided for the banishment of a player who breached the contract by contracting with any other team which was not a member of the American and National Leagues. ${ }^{100}$

These restrictions gave Major League Baseball domination over the White player market so that it could dictate the prices paid for labor in that market. The restrictions on individual liberty and compensation levels made the reserve system the target of frequent challenges by players, sometimes successfully, in the lower federal and state courts. For example, in Gardella v. Chandler, ${ }^{101}$ Daniel Gardella sued to challenge his banishment from the Major Leagues when he violated the reserve clause by playing professional baseball in the Mexican League. The Second Circuit Court of Appeals reversed the district court and allowed Gardella to sue on antitrust grounds. ${ }^{102}$ In Martin v. National League Baseball Club, ${ }^{103}$ the Second Circuit upheld a lower court's refusal to enjoin a player's banishment, but only because of a defect in the pleadings. ${ }^{104}$ Courts historically have been inconsistent in the issuance of such injunctions. ${ }^{105}$

In addition to the power to dictate prices paid for players, the reserve system suppressed the supply of professional players available for competitors. The precise accusation in Federal Baseball Club of Baltimore v. National League of Professional Base Ball Clubs, was that the Major Leagues had "conspired to monopolize the base ball business"

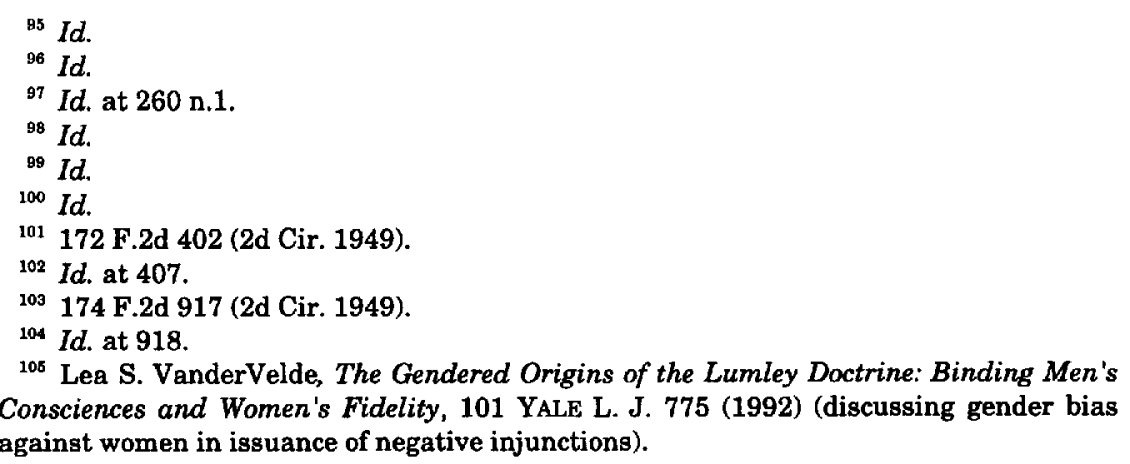


through the use of the reserve system. ${ }^{106}$ The Federal Baseball Club of Baltimore was a member of the Federal League which had competed with the American and National Leagues. The latter leagues bought out or induced every team in the Federal League except the Baltimore club to join them. The gist of the Baltimore club's antitrust claim was that the reserve system dried up the pool of skilled and talented players that the Baltimore club needed to compete.

By this agreement players, before they could secure employment in any club operating under it, were required to enter into contracts which, it is alleged, gave the appellants control over practically all available players of sufficient skill to serve in a Major League club, and thus the Federal League was unable to secure players capable of producing such exhibitions of baseball as the public demanded; and, in consequence of this inability, disaster came upon the Federal League and its constituent clubs .... ${ }^{107}$

Similar claims were made nearly forty years later in Toolson $v$. New York Yankees. ${ }^{108}$ The complaints in that case contained numerous allegations of the Major Leagues' control over the prices paid for players through salary caps and wage scales. ${ }^{109}$ The plaintiffs also alleged that Major League Baseball's monopoly extended beyond the player market to professional baseball in the United States. The complaints contained detailed allegations of territorial and broadcast restrictions. Moreover, the complaint in Corbett $v$. Chandler contained allegations about Major League Baseball's efforts to control and dominate the minor leagues by acquiring minor league clubs as farm teams of the Major League teams. ${ }^{110}$

Branch Rickey pioneered the utilization of the White minor leagues as farm systems of the Major Leagues. ${ }^{111}$ Players in those minor leagues were also subject to the reserve system. ${ }^{112}$ A player signing a minor league contract was subject to restraints like those of the Major Leaguers. However, White minor league teams developed players and made money by assigning the contract rights to their stars to Major League teams. The minor leagues thus controlled the market for White

\footnotetext{
${ }^{106}$ Federal Baseball Club v. National League of Profl Baseball Clubs, 259 U.S. 200, 207 (1922).

${ }^{107}$ Federal Baseball Club v. National League of Prof'l Baseball Clubs, 269 F. 681, 683 (D.C. Cir. 1920).

${ }^{108} 346$ U.S. 356, 362-64 (1953) (Burton, J. dissenting). Toolson actually involved two other cases that were consolidated for hearing in the Supreme Court; Corbett $v$. Chandler and Kowalski v. Chandler.

${ }^{109}$ Toolson Record at 9-10, 12-18.

${ }^{110}$ Id. at 5.

111 Geoffrey C. Ward \& Ken Burns, Baseball 148-49 (1994).

112 Federal Baseball, 269 F. at 687.
} 
players who did not possess or not yet possess Major League skills. ${ }^{113}$ Branch Rickey drove the cost down for the Dodgers by acquiring ownership interests in minor league teams. He promoted the establishment of formal ties between Major League teams and minor league teams to allow the Major League teams to grow their own talent. ${ }^{114}$

Major League Baseball's monopoly was so powerful that it was virtually impossible to own and operate a professional baseball team in the United States without the explicit or tacit consent of the Major Leagues. The Major Leagues not only directly dictated prices in the player market but controlled the entry of firms into the market. The implications of this extensive control on the Negro Leagues is obvious. They were able to exist or survive only with the consent of the Major Leagues. This reality for the Negro Leagues is only highlighted by the failure of the Major Leagues, the minor leagues, or many would-be entrants to recognize their existence before or after Jackie Robinson.

The plaintiff in Federal Baseball erroneously maintained that all professional baseball players in the United States were under the control of the Major Leagues. In all fairness, the Negro Leagues had not yet been formed at the time of the complaint, but there were Black professional players. The failure to acknowledge their existence continued in Toolson. The complaints filed in 1951 contained descriptions of the history of Organized Baseball in the United States but did not include a single reference to the Negro Leagues. The omission of the Negro Leagues in that history continued in Congressional proceedings. The Report of the 1958 antitrust hearings also contains a history of professional baseball without any reference to the Negro Leagues. ${ }^{115}$

Despite the omission of the Negro Leagues in its then official history, Major League Baseball was very aware of their existence and its ability to determine their fate. There is evidence that the Major Leagues considered that the Negro Leagues would not simply die out if the Major Leagues signed Black players, but that the Major Leagues had the power to destroy them. The owner of the Washington Senators is reported to have acknowledged as much in a meeting with two stars of the Negro Leagues.

Finally, Griffith [the owner of the Washington Senators] called [Josh] Gibson and [Buck] Leonard into his office.... Ric Roberts is talking

113 That relationship has been rocky. See Portsmouth Baseball Corp. v. Frick, 278 F.2d 395 (2nd Cir. 1960) (addressing the Major League-minor league relationship).

114 Major League clubs owned minor league teams or entered into "working agreements" to establish a farm system of minor league teams. Hearings, supra note 44, at 197-99.

${ }^{115}$ Id. at 193-94. 


\section{2 / Vol. 35 / American Business Law Journal}

about getting you fellows on the Senators' team. Well, let me tell you something. If we get you boys, we're gonna get the best ones. It's gonna break up your league. Now what do you think about that? ${ }^{116}$

The comments seem to imply both the application of the integration premise and the recognition of the Major Leagues' monopoly position. The Major Leagues were wealthier and could outbid the Negro League teams. That only explains their acquisition of the stars; it does not explain their destruction of the Negro Leagues, which could only have been accomplished through the exercise of the monopoly power Major League Baseball had over the player market.

The death knell of the Negro Leagues thus appears to have sounded not from the loss of their stars, but from the use by the Major Leagues of its monopoly power. First, the Major Leagues subjected Black players to its reserve system, allowing it to dictate their price. Black players who thereafter reached the majors were subject to the reserve system once they signed their first Major League contract. Jackie Robinson was not free to return to the Negro Leagues. Players were free, however, to return if the Major Leagues lost interest as they did with Satchel Paige. Integration thus meant that Negro League teams had to compete for players in the market for professional baseball players over which the Major Leagues maintained a monopoly. Second, in another exercise of monopoly power, the Major Leagues eventually circumvented the Negro Leagues by using their own scouting systems and signing Black players out of high school, thereby cutting off the Negro Leagues from the pool of potential talent as well. ${ }^{117}$

Third, after the Negro Leagues lost their imprimatur as a major league of baseball, ${ }^{118}$ they were precluded from operating as a minor league to develop the talent pool of young African-American players. Some teams did establish a relationship with Major League teams for a while as unofficial farm clubs. ${ }^{119}$ That function, however, was usurped by the Major Leagues with its use of the minor league farm system from which Black players had also been excluded. When the Major League teams started signing African-Americans out of high school, many of them, as did Jackie Robinson, signed minor league contracts first. The Negro Leagues were thus excluded from a possible niche as a developer

${ }^{116}$ HOLWAY, supra note 38 , at 86-87.

117 Id. at 71.

${ }^{118}$ Interestingly, the cases involving Major League Baseball's reserve system generally fail to acknowledge the existence of the Negro Leagues. In Flood v. Kuhn, 407 U.S. 258, 262 (1972), Justice Blackmun listed Satchel Paige among the greatest players in baseball history but the opinion did not otherwise mention the Negro Leagues. The inclusion of Jackie Robinson cannot be viewed as a tribute to them.

119 DIxon, supra note 4, at 303-4. 
and nurturer of African-American talent. The Federal League became extinct in part because it could not sign players once they were under a minor league contract. One of the anticompetitive effects of the use of the Major Leagues' monopoly power to eradicate the Negro Leagues was that the number of professional opportunities for White and Black players in the United States decreased.

\section{STRATEGIES FOR SURVIVAL}

There are two basic scenarios under which some remnant of the Negro Leagues could have survived. The best prospect for the leagues themselves would have been as a minor league in which the players were predominantly Black. The Negro Leagues could not have continued as an isolated major league, but one or more of the teams may have. Instead of integrating Black players into the player market, the Negro Leagues as a group may have been able to force a merger with, or gain the admission of one or more teams into, the Major Leagues. The result would have been teams with Black owners and Black players. Eventually, there may have been White players, but given the social climate, it would have taken a while. Perhaps, inconceivable at the time because of racial realities, the Negro Leagues had considerable leverage. Simply put, players of exceptional skill were essential to producing Major League baseball. Without access to the players, a team could not market Major League baseball to the public. The Negro Leagues had a substantial number of such players, but showed no signs that they appreciated the leverage that they had for shaping integration on their terms. ${ }^{120}$ No plan for survival was possible without a legal strategy to effectuate it. At the time, legal recourse lay most likely in antitrust law, because the monopoly power of the Major Leagues was then under assault in the courts, and civil rights law, because segregation in other venues was then under siege in the courts. ${ }^{121}$ There is no indication that the Negro Leagues considered any such strategy to bring Negro League teams into the Major or minor leagues.

\footnotetext{
${ }^{120}$ Obtaining access to the players was an essential part of the subsequent strategy of the American Football League to force a merger with the established professional league. The AFL's efforts are reflected in cases such as Houston Oilers $v$. Neely, 361 F.2d 36 (10th Cir. 1966) (AFL club sought injunction against player who tried to jump his AFL contract to play in the NFL); New York Football Giants v. Los Angeles Chargers Football Club, 291 F.2d 471 (5th Cir. 1961) (NFL team sued AFL team over player's services who had signed contracts with both teams); and Los Angeles Rams Football Club v. Cannon, 185 F. Supp. 717 (S.D. Cal. 1960) (NFL sued to enjoin a player who tried to revoke his NFL contract to play in the AFL). For a more detailed account, see MARK RIBOWSKY, SLICK: THE SILVER AND BLACK LIFE OF AL DAVIS (1991).

121 The American Football League precedent is applicable here as well, as it resorted to antitrust litigation which ultimately led to a merger. American Football League v. National Football League, 323 F.2d 124 (4th Cir. 1963).
} 


\section{An Antitrust Strategy}

The Negro Leagues could have embarked upon a two pronged antitrust strategy. First, the exemption of baseball from the antitrust laws provided by Federal Baseball was not the exclusive province of the Major Leagues. It also applied to the Negro Leagues, notwithstanding the failure of the courts to acknowledge their existence. Accordingly, the Negro Leagues could have utilized the exemption to develop a reserve system so that they would strengthen their control over the market for Black professional baseball players. With a strong reserve system in the Negro Leagues, Branch Rickey could not have signed Jackie Robinson without negotiating with the Negro League owners, and they could have insisted upon a Federal League-type solution. They also may have been able to negotiate a reciprocal hands-off agreement similar to the compact reached by Commissioner Albert Chandler with the Mexican Leagues to honor the reserve systems of each other. ${ }^{122}$

The affirmative use of the exemption would have had several drawbacks. A reserve system would have run counter to the culture of contractual freedom in African-American society. The owners would have encountered substantial criticism for pursuing their own greed at the expense of the players. Such criticism did appear when the Negro Leagues established a uniform player contract after the Kansas City Monarchs failed to receive compensation for Jackie Robinson. ${ }^{123}$ The system would have required a stronger relational contract system than existed in the Negro Leagues. Not only would the Leagues have had to enforce the system against players, but they also would have needed the power to keep team owners in line. As noted above, the owners frequently left the Leagues out of economic necessity. Moreover, they would have encountered considerable difficulty in enforcing the reserve system. The strategy would have required the availability of experienced commercial counsel, and such lawyers were scarce in African-American communities. ${ }^{124}$

Second, the Negro Leagues could have pursued an antitrust litigation strategy against the Major and minor leagues. Federal Baseball was under challenge in the 1940s. In fact, at the time the Supreme court decided Toolson, there were at least seven additional cases pending in the lower courts. ${ }^{125}$ One can only wonder how the

${ }^{122}$ Hearings, supra note 44 , at 684 .

${ }^{123}$ DIXON, supra note 4, at 305-06.

${ }^{124}$ John T. Baker, Black Lawyers and Corporate and Commercial Practice: Some Unfinished Business of the Civil Rights Movement, 18 How. L. J. 685, 686 (1975); J. Clay Smith, Justice and Jurisprudence and the Black Lawyer, 69 NOTRE DAME L.R. 1077 (1994).

${ }^{125}$ Hearings, supra note 44, at 197. 
Supreme Court would have decided Toolson if the Negro Leagues, or any of its owners, had brought one of the companion cases. That claim would only have been strengthened when the Major Leagues allowed several clubs to move to new cities in the 1950s. These included the well-known move of the Dodgers and Giants to the West Coast in 1958, and the lesser known moves of the St. Louis American team to Baltimore in 1954, and the Philadelphia American League team to Kansas City in 1955. The move to Kansas City is especially notable because a successful Negro League team, the Monarchs, had operated there.

The Negro Leagues would have added a completely different and powerful dimension to the legal argument that Federal Baseball was no longer good law. It would have been decided in the same year as Brown $v$. Board of Education I, and the Supreme Court would have had to answer whether the exemption extended so as to permit baseball to segregate the professional baseball market. One effect of such a ruling would have been the use of commercial law to address racial discrimination in the commercial context.

The claim need not have been limited to section 1 of the Sherman Antitrust Act. As the financial health of teams declined after the signing of Jackie Robinson, the teams could have pursued a claim of unlawful monopolization under section 2 of the Sherman Act. The Major Leagues would have had to defend a case claiming that it had directly used its monopoly power first to segregate the market for professional baseball players and then to destroy the businesses that had invested in it.

\section{The Civil Rights Strategy}

The Negro Leagues and its teams may have pursued a civil rights strategy. While history has recorded the NAACP's legal strategy to desegregate public schools, little attention has been given to the effort to desegregate sports facilities in public parks, most notably golf courses. The earliest reported battleground was in Baltimore, in Durkee $v$. Murphy, in 1942. ${ }^{126}$ It was followed by Law v. Mayor and City Council of Baltimore, in $1948^{127}$ and Boyer v. Garrett in $1949{ }^{128}$ The legal fight moved to Houston in Beal v. Holcombe, in $1950 .{ }^{129}$ The legal theory of these cases was that the golf facilities provided to Blacks when compared to those provided to Whites violated the "separate but equal" doctrine of Plessy $v$. Ferguson. ${ }^{130}$ Cases challenging racially segregated

\footnotetext{
12629 A.2d 253 (1942).

12778 F. Supp. 346 (D. Md. 1948).

${ }^{129} 88$ F. Supp. 353 (D. Md. 1949), affd, 183 F.2d 582 (4th Cir. 1950).

${ }^{129} 103$ F. Supp. 218 (S.D. Tex. 1950), rev'd, 193 F.2d 384 (5th Cir. 1951).

130163 U.S. 537 (1896).
} 
golf courses have continued into contemporary times, but the focus has switched to challenging private facilities. ${ }^{131}$ These cases were brought under the principle of Brown v. Board of Education ${ }^{132}$ and modern civil rights statutes such as Title II of the Civil Rights Act of $1964 .{ }^{133}$

The theories under which those cases were brought would not have worked for the Negro Leagues, as they already had access to public facilities or at least the same facilities in which Major League teams played. Negro League teams customarily rented Major League stadia while the home team was away. An example of the practice may be found in Dodier Realty, which involved a rent dispute over whether the Cardinals were obligated to pay for electricity when Negro teams used its stadium. ${ }^{134}$ Even if Negro League teams had been denied the use of Major League stadia, a lawsuit giving them access in some cities may have been a pyrrhic victory. The Negro League team would have needed fans in the stadium and those fans left them after the Negro League stars deserted them for the Majors.

The only plausible strategy would have been to challenge discriminatory refusals to permit Negro League teams to join the Major Leagues, recognize them as a minor league or join the National Association of Professional Baseball Clubs, the official association of various minor leagues. That would have required the Negro Leagues or member teams to make such requests. Even this strategy would have necessitated a novel legal strategy, but the Civil Rights Movement prided itself on the development of novel legal theories. The specific problem was to find a law that made discrimination in commercial dealings illegal, and as indicated above, Professor Suggs has argued that there is no such law. ${ }^{135}$

It was theoretically possible to have brought an action under the Civil Rights Act of $1870 .{ }^{136}$ After Jones $v$. Alfred H. Mayer Co ${ }^{137}$ was decided in 1968, the lower federal courts recognized and construed section 1981 to prohibit racial discrimination in contracting. Since membership

${ }^{131}$ See, e.g., Brown v. Loudoun Golf and Country Club, Inc., 573 F. Supp. 399 (E.D. Va. 1983) (challenge to a private club's admission policy); Wright v. Salisbury Club, Ltd., 479 F. Supp. 378 (E.D. Va. 1979), rev'd, 632 F.2d 309 (4th Cir. 1980) (same); Wright v. Cork Club, 315 F. Supp. 1143 (S.D. Tex. 1970) (same).

132349 U.S. 294 (1954). See also Watson v. City of Memphis, 303 F.2d 863 (6th Cir. 1962) (challenge to racial segregation in city parks), rev'd, 373 U.S. 526 (1963); Evans v. Laurel Links, Inc, 261 F. Supp. 474 (E.D. Va. 1966) (challenge to racially segregated golf course). ${ }^{133} 42$ U.S.C. \& $2000 a(b)(3)$, (c) (1994).

${ }^{134}$ Dodier Realty \& Inv. Co. v. St. Louis Nat'1 Baseball Club, Inc., 238 S.W.2d 321 (Mo. 1951).

${ }^{135}$ See supra note 91 and accompanying text (describing lack of legal protections against discrimination in business transactions).

${ }^{136} 42$ U.S.C. § 1981a (1994); 42 U.S.C. \& 12117(a) (1994).

${ }^{137} 392$ U.S. 409 (1968). 
in a league involves a contractual relationship, a refusal to admit Negro League teams would have been a refusal to enter into or make a contract. The Supreme Court upheld causes of actions under section 1981 , as the Act is commonly referred to, challenging racial discrimination in contracting in Runyon $v$. McCrary. ${ }^{138}$ That case, however, was not decided until 1976. In Patterson v. McClean Credit Union, ${ }^{139}$ the Supreme Court limited causes of action under section 1981 to those based on discriminatory refusals to form contracts. That limitation is still broad enough to reach an action for a discriminatory refusal to admit a Negro League team to the Major or minor leagues.

Antidiscrimination law may have provided a legal strategy for the survival of the Negro Leagues as minor leagues or of some teams as Black-owned teams. Nevertheless, antidiscrimination law eventually would have restricted the ability of the Negro Leagues to be teams explicitly comprised of Black players. Under Title VII of the Civil Rights Act of 1964, Negro League teams which made color a condition of employment would have been in violation of Title VII and section 1981, not to mention state antidiscrimination laws. ${ }^{140}$ Although in the 1960s such teams were viable under the then status quo, they could have expected to have been sued in the same manner as historically Black colleges and universities. ${ }^{141}$

\section{CONCLUSION}

This article has argued that it may have been possible for some of the Negro Leagues, their teams, or owners to have survived in some fashion. Perhaps the best opportunity for the Negro Leagues, that is teams comprised of Black players and Black owners, to have survived may have been as a developer and nurturer of young talent. Yet, the history of Black high schools in the era after Brown $v$. Board of Education suggests that some teams may have survived under Black ownership with integrated players as members of a minor league. It is virtually unthinkable that a Black-owned franchise with integrated players could have joined the Major Leagues in the social milieu of that era, although Negro Leaguers barnstorming against teams comprised of White Major Leaguers was not uncommon. Given the talent in the Negro Leagues, the absorption of one or more teams may have been a possibility if the Negro League owners had understood the forces they

\footnotetext{
138427 U.S. 160 (1976).

139491 U.S. 164 (1989).

14042 U.S.C. $\$ 2000$ (1994).

${ }^{141}$ See Whiting $v$. Jackson State Univ., 616 F.2d 116 (5th Cir. 1980), and similar cases where Whites have successfully sued historically Black colleges and universities for employment discrimination.
} 
318 / Vol. 35 / American Business Law Journal

faced, if the civil rights community had been as supportive of the owners as they were of the players, and/or if White owners could have overcome their bigotry. Perhaps neither Negro League owners nor other observers of the day could see the power that hit the Negro Leagues any better than they could have seen a Satchel Paige pitch. ${ }^{142}$

${ }^{142}$ Security Union Title Ins. Co. v. Superior Ct., 281 Cal. Rptr. 348, 353 (1991). 